\title{
(ㄷ)
}

Research Paper

EPRA International Journal of Economic and Business Review-Peer Reviewed Journal

Volume - 9, Issue - 9, September 2021 | e-ISSN: 2347 - 9671| p- ISSN: 2349 - 0187

\section{ENTREPRENEURSHIP AND ECONOMIC GROWTH NEXUS IN NIGERIA: MODERATING EFFECT OF INSTITUTIONAL QUALITY: ARDL COINTEGRATION APPROACH}

\author{
Yusuf Shamsuddeen Nadabo ${ }^{1 *}$, Suleiman Maigari Salisu ${ }^{2}$ \\ ${ }^{1}$ Department of Economics, Maryam Abacha American University of Niger \\ ${ }^{2}$ Department of Economics, Umaru Musa Yar'adua University, Katsina
}

*Corresponding Author

ORCID iD: 0000-0001-5023-6079

\begin{abstract}
DOI No: 10.36713/epra8385

Article DOI URL: https://doi.org/10.36713/epra8385

This paper explores the relationship between entrepreneurship and economic growth in Nigeria: the moderating role of institutional quality. To accomplish this, the study employs an Autoregressive distributed lag (ARDL) from (2002Q1-2019Q4) and uses a moderator model to examine the impact of entrepreneurship on economic growth via institutional quality. The resilts show that institutional quality in Nigeria has a positive impact on economic growth. The results also indicate that the interactive effect of institutional quality and entrepreneurship has positive effect on economic growth in Nigeria both in the short-run and long-run. The study illustrate that the productive entrepreneurship is a potent vehicle for promoting long term economic growth in Nigeria. In general, unless institutional quality is introduced to improve the influence of entrepreneurship on economic growth, entrepreneurial activity alone may not lead to desired growth. Furthermore, the study presents a perspective of the role of government in establishing an enabling environment that promotes entrepreneurial activity and, as a result, enhances economic growth in Nigeria. Based on this finding, the study recommends for the implimantation of measures and policies aims at encourageing productive entrepreneurial activities that contribute to economic growth. In addition Government and policymakers should improved the quality of institutions such as improving Government Effectiveness, Political Stability and Absence of Violence, Voice and Accountability, Regulatory Quality, Rule of Law and Control of Corruption.
\end{abstract}

KEYWORDS: Economic growth, Entrepreneurship, Moderating, Institutional quality.

\subsection{INTRODUCTION}

Economic growth is a crucial concern for economies worldwide; economic growth refers to an economy's ability to enhance its production capacity, producing more units of goods and services. This economic growth is also considered as a holly grain for economic strategies that use numerous economic indicators to gauge a country's growth or development, such as the human development index, total factor productivity, entrepreneurship, gross domestic product growth rate, institutions, and so on (Smyth, 1995). 
Global economic growth is predicted to accelerate From 2.9 percent in 2019 to 3.3 percent in 2020 and 3.4 percent in 2021. World Economic Outlook. (WEO, 2020). SSA's economic growth is expected to be 3.4\% in 2019, the same as in 2018. Although constant, this pace is lower than the sub-decadal region's average of 5\% growth. According to the African Economic Outlook for 2021, growth will climb to 3.9 percent in 2020 and 4.1 percent in 2021. (AEO, 2020). In 2021, the GDP growth rate is predicted to rise to 1.7 percent, according to the International Monetary Fund (IMF, 2020).

Nigeria's economy experienced a recession in 2020, reversing three years of gains due to a dip in crude oil prices due to dropping global demand and containment attempts to combat the spread of COVID-19. The containment measures impacted aviation, tourism, hospitality, restaurants, manufacturing, and trade. On the other hand, demand-driven expansion in the financial and information and communications technology sectors Contraction in some places countered the expansion. Overall, real GDP is predicted to contract by $3 \%$ in 2020 , according to the Bank, notwithstanding mitigating measures contained in the Economic Sustainability Programme (ESP) kept the decline from being significantly worse. Higher food costs due to domestic supply limits and the passthrough effects of an exchange rate premium that increased to nearly 24 percent propelled inflation to 12.8 percent in 2020, up from 11.4 percent in 2019. In addition, fuel subsidies are being removed, and an increase in power costs intensified inflationary pressures. As a result, Nigeria's Central Bank cut the policy rate by 100 basis points to 11.5 percent to strengthen the economy. to boost the economy. (AEO, 2020).

However, reflecting pandemic-related spending pressures and revenue deficits, the budget deficit expanded to 5.2 percent in 2020 from 4.3 percent in 2019, financed mainly by domestic and foreign borrowing. Total government debt was $\$ 85.9$ billion (25 percent of GDP) on June 30, 2020, up 2.4 percent from the previous year. Domestic debt accounted for $63 \%$ of overall debt, while external debt accounted for $37 \%$. Nigeria faces a huge fiscal risk due to high debt service payments, and it is estimated to generate more than half of the revenue collected by the federal government. It was predicted that the current account deficit was forecast to stay at 3.7 percent of GDP, owing to a drop in oil receipts and sluggish external financial flows (AEO, 2020).

Furthermore, many scholars contend that entrepreneurship is crucial because of its capacity to generate economic growth and progress (Acs, 2006; Acs et al., 2018; Acs \& Szerb, 2007; Audretsch et al., 2006; Baumol, 1986; Baumol \& Strom, 2007; Bosma et al., 2018; Braunerhjelm et al., 2010; Schumpeter, 1934; Wennekers \& Thurik, 1999; Fritsch and Wyrwich 2017; Dvoulety 2017; Bjørnskov and Foss 2016; Prieger et al. 2016; Yusuf 2021). For example, the endogenous growth theory (Lucas, 1988; Romer, 1986, 1990) claims that economic growth is based on collecting and disseminating knowledge through incumbents and entrepreneurial activities (Braunerhjelm et al., 2010). Investments in human capital and research and development not only provide knowledge for incumbents but also knowledge spillovers for new entrepreneurs (Acs et al., 2009; Audretsch \& Keilbach, 2007; Braunerhjelm, Ding \& Thulin 2018) and allow for increased competition and product supply, resulting in economic growth (Minniti \& Lévesque, 2010).

In addition, Adusei (2016) later argued that entrepreneurship could not contribute to economic growth because many developing countries are at the pinnacle of technological development, making it difficult for small and medium-sized businesses (SMEs) to innovate and flourish. As a result, some researchers propose that a national entrepreneurial ecosystem be formed or at the very least the reduction of barriers to a business entrance, is indeed a place for public entrepreneurship policies and assistance (e.g., Muoz and Otamendi 2014) and Another perspective suggested by Antony, Klarl \& Lehmann (2017), Naudé (2011), or North (1990) is that the problem in developing countries is the imperfection of public institutions. The GEM scholars (e.g., Bosma et al. 2012) have also raised this issue, arguing that if the government fails to establish the rule of law, the positive effect of entrepreneurship may be diminished. Obeng and Robson \& Freel (2008) and The imperfection of the financial system (difficult access to financial capital by new entrepreneurs), poor entrepreneurship infrastructure, high levels of corruption, unfavorable trade policy, inefficient state policy, and poor human resource management are all mentioned as problems in developing economies (Altenburg and Lütkenhorst 2015).

Moreover, Nigerian entrepreneurship is driven by two distinct perspectives (necessity-driven and opportunity-driven). Entrepreneurs are motivated by a need or an opportunity to engage in business operations. Necessity-driven entrepreneurial activities as a feature of informal economic sectors, and opportunity-driven entrepreneurial activities as a characteristic of formal economic sectors. These economic frameworks have been observed to have heightened individual venture desirability in Nigeria today. Before starting a business, the majority of entrepreneurs exhibited job-seeking behavior. (Clark and Drinkwater 2000; Wagner 2007).

In Nigeria, for example, the Small and Medium Enterprises Agency (SMEDAN). This is a federally financed organization that oversees the affairs of Nigeria's small and medium businesses, The Bank of Industry (BOI) was founded to provide long and short-term lending to small and medium-sized enterprises at competitive interest rates, 
Microfinance Banks these have lately taken the position of the former Community Banks, and their purpose is to offer long-term funding for small and medium-sized businesses, Agricultural and Rural Development Bank of Nigeria (ARDBN) the previous Peoples Bank, which is being reorganized to provide small-scale lending and guarantees in rural areas, is now housed in this development finance bank. Its purpose is to give money for agricultural entrepreneurship in rural areas. In addition, the Small-Medium Enterprises Equity Investment Scheme is a government-run program that invests in small and medium-sized businesses (SMEEIS), Government Enterprise and Empowerment Programme (GEEP), the Youth Enterprise with Innovation in Nigeria (You-win) program, Subsidy Reinvestment Program (Sure-P), National Directorate of Employment (NDE), National Open Apprenticeship Scheme (NOAS), the NEEDS, NAPEP, and the N-Power initiative. All these policies and much more are targeted towards promoting entrepreneurship. However, despite these laudable policies put in place by the governments in Nigeria, the performance in the entrepreneurial activities has been unsatisfactory, as evidenced by lower GDP growth rate and low new firm entry density, respectively, compared to other developing countries in the world.

By and large, entrepreneurial activity alone may not lead to desired growth, except the institutional quality is brought in to improve the impact of entrepreneurship on economic growth; the role of Institutions in promoting entrepreneurship and economic growth has been acknowledged in the literature (North 1990, Audretsch, \& Keilbach, 2004; Van Stel, Carree, \& Thurik, 2005; Braunerhjelm et al., 2010; Hessels et al., 2011; Iman, 2017; Okesola et al., 2017; Stoica, Roman \& Rusu 2020).

This is based on the belief that high-quality institutions are critical in creating a conducive environment for economic development for Nigeria's impoverished citizens. Thorbecke (2013), Iheonu, Ihedimma, and Onwuanaku (2017), Parks, Buntaine, and Buch (2017), and others have stressed the need for excellent institutional quality in ensuring long-term growth and development. For example, Asian economies have seen tremendous economic success due to high-quality institutions, but African economies, such as Nigeria, have high levels of unemployment and poverty. As a result, governments and multilateral agencies have shifted their focus to getting institutions right in developing countries by emulating developed-country institutions (Rodrik, 2008). However, despite global institutional harmonization, there is little consensus on the effectiveness of these reforms (Andrews, 2013).

Institutions in underdeveloped countries are primarily redistributive, establishing monopolies instead of competitive conditions and restricting opportunities rather than growing them. As a result, these institutions rarely lead to investments that boost productivity (Yildirim \& Gokalp, 2016). Furthermore, institutional variables such as the distribution of political and civil rights, the quality of the legal system, and government performance are likely to influence accumulation in Africa (Epaphra \& Kombe, 2018). According to Owasanoye (2019), African countries lose $\$ 90$ billion annually due to illicit money flows to other countries, mostly from Nigeria. Institutional weakness is one of the key causes of this setback.

Improvement in the institutional quality in Nigeria could be a possible remedy for low entrepreneurial activity. Therefore, the study hypothesises that improved entrepreneurial activity will enhance productivity, whereas productivity improvement will improve economic growth and, by extension, business continuity, poverty reduction, and employment creation. The main objective of the research is to examine the relationship between entrepreneurship and economic growth nexus in Nigeria: moderating role of institutional quality while the specific objectives are as follows:

i. $\quad$ To explore the effect of entrepreneurship on economic growth in Nigeria.

ii. To investigate the interaction effect of institutions and entrepreneurship on economic growth in Nigeria.

\subsection{LITERATURE REVIEW \\ Theoretical Literature \\ Endogenous Growth Theory}

Endogenous growth theory holds that economic growth primarily results from endogenous and not external forces (Romer, 1993). According to the theory, investing in human capital, innovation, and knowledge is significant to economic growth. It also focuses on positive externalities and spills over the effects of a knowledge-based economy, leading to economic development. The theory primarily holds that the long-run growth rate of an economy depends on policy measures. For instance, subsidies for research and development or education increase the growth rate by increasing the incentive for innovation. 


\section{Entrepreneurship theory}

Opportunity is the central construct of entrepreneurship theory (Venkataraman \& Shane, 2000). Schumpeter (1942) suggested that those creative destruction processes occur when new opportunities displace existing business models. Entrepreneurs are said to find, make and recognize these opportunities (Alvarez and Barney, 2007; Sarasvathy et al., 2003). Eckhardt and Shane (2003) suggest opportunities are "circumstances in which new raw materials, markets, goods, services, and arrange techniques can be introduced through the formation of new means, ends or means-ends relationships."

\section{The New Institutional Economics (NIE)}

The emergence of the New Institutional Economics (hereafter, NIE) approach shared common intellectual ground on institutional economics that institutions matter. Moreover, it suggests that institutions determine the economic performance differentials across countries (North, 1994). Interestingly, Williamson (1998) observed that NIE is inherently an interdisciplinary undertaking, which includes works in property rights analysis, the economic analysis of the law, public choice theory, constitutional economics, the theory of collective action, transaction cost economics, the principal-agent approach, the theory of relational contracts, and comparative economic systems. What remains common in these approaches is that, unlike neoclassical economics, the NIE framework is not assumed as given but is explicitly treated as an object of research. (Richter, 2005).

\section{EMPIRICAL LITERATURE}

\section{Empirical Literature on Entrepreneurship and Economic growth}

Urbano and Aparicio (2016) the study examined the effect of different types of entrepreneurship capital (overall total entrepreneurial activity (TEA), opportunity TEA, and necessity TEA) on economic growth in 43 countries for the period 2002-2012. The results show that entrepreneurship is a key driver of economic growth in all of the nations studied. The authors also discover that the positive effect of overall TEA on economic growth is stronger in OECD countries than in non-OECD countries.

Lepojevic, Djukic \& Mladenovic (2016) demonstrated that entrepreneurial activity positively impacts economic growth, higher in developed countries than in underdeveloped countries. Furthermore, the authors claimed that in industrialized countries, opportunity-based entrepreneurship has the largest impact on economic growth (as measured by the GDP growth rate), followed by high expectation entrepreneurship, while necessity-based entrepreneurship has the least impact in developing countries.

Doran, McCarthy \& O'Connor (2018) examine the impact of different entrepreneurship types on economic growth depending on a country's economic development stage. In high-income countries, entrepreneurial mindsets have a positive effect on GDP per capita. However, according to the authors, nations but entrepreneurial activity negatively affect middle- and low-income countries.

Boudreaux, Nikolaev \& Klein (2019) Investigates that opportunity-motivated entrepreneurship positively affects economic growth in middle and high-income countries, while necessity-motivated entrepreneurship has a negative effect on economic growth in low-income countries; from 2004 to 2011, panel data for 55 rich and developing economies was used.

Wong, Ho \& Autio (2005) study explore the impact of technological innovation and new firm formation on growth. They are using cross-sectional data on 37 countries participating in Global Entrepreneurship Monitor (GEM) in 2002. The finding is that the rapidly growing new firms generate most of the new job creation by small and medium enterprises in developed countries. The result also shows that there is a positive effect of innovation on economic growth.

Feki \& Mnif (2016) investigate the link between entrepreneurship and economic growth. The study uses a panel of 35 developing countries for the periods 2004-2011. Their results suggest a significant and positive correlation between entrepreneurship and growth, and the effect of technological innovations on economic growth is positive and significant only in the long term.

$\mathrm{Li}$ et al. (2012) study the impact of entrepreneurship on China's economic growth by using a panel of 29 provinces for the periods (1983-2003). Their result suggests that entrepreneurship has a significant and positive effect on economic growth. Moreover, the result is still robust even after they control for other demographic and institutional variables.

Coulibaly, Erbao \& Mekongcho (2018) attempt to analyze the impact of globalization and entrepreneurship on rapid economic growth and development in BRICS emerging nations (Brazil, Russia, India, China, and South Africa). For the period 2002-2013. Their study shows that entrepreneurship and economic globalization both have a significant and positive impact on the economic development of BRICS. 
Fritsch and Wyrwich (2017) investigate the relationship among a regional culture of entrepreneurship, startup activity, and regional development for 70 planning regions of West Germany. The result of their study reveals that German regions with a high level of entrepreneurship in the mid-1920s have higher start-up rates about 50 years later. Hence, a regional culture of entrepreneurship is an essential factor for the persistence of entrepreneurship.

Audretsch, Belitski, and Desai (2015) identified the relationship between entrepreneurship and economic development. They were using a panel of 127 European cities between 1994 and 2009. They found that new-firm start-ups' immediate economic development impact is positive for large, small, and medium-sized cities.

Vuong et al., (2020) explore the relationship between entrepreneurship and economic growth and the determinants of entrepreneurship in emerging countries for 13 emerging countries from 2002 to 2013. The findings indicate that entrepreneurship is positively related to economic growth.

Boudreaux and Caudill (2019) investigate Entrepreneurship, Institutions, and Economic Growth: Does the Level of Development Matter? Using a panel of 83 countries for the periods 2002 to 2014. find that opportunitymotivated entrepreneurship encourages economic growth in developed countries, while necessity-motivated entrepreneurship discourages economic growth in developing countries.

Stoica, Roman\& Rusu (2020) examine the nexus between entrepreneurship and economic growth: a comparative analysis on groups of countries. They are using the panel data, which covers 17 years (2002-2018). According to the findings, all three types of entrepreneurship have a stronger impact on economic growth across the entire sample of European countries. However, some types of entrepreneurship are more essential than others. Furthermore, we discover that opportunity-driven entrepreneurship and early-stage entrepreneurship are important variables in boosting economic growth throughout the sample of European countries.

\section{Empirical Literature on Institutions and Economic growth}

Valeriani and Peluso (2011) analyse the impact of institutional quality on economic growth and development: an empirical study of Sub-Saharan Africa, Latin America and Caribbean, North America Middle East and North Africa, Europe and Central Asia, East Asia and Pacific South Asia. The study used pooled regression model and a fixed-effects model from 1950 to 2009. Results show that institutional quality does influence economic growth positively.

Devangi and Lee (2013) Study investigates whether economic growth and institutional quality contributed to poverty and inequality reduction in South Asia, East Asia, India, Pakistan, Bangladesh, and Sri Lanka. The study use System (GMM) estimation 1985-2009. Results show that corruption, democratic accountability, and bureaucratic quality are associated with worsening income distribution.

Dandume (2013) investigates institutions and economic growth performance in Nigeria for the period 19802011. The study uses the ARDL approach to cointegration and causality. Findings show that corruption has a positive effect on economic growth. In addition, the result for the Granger Causality test reveals that institution and economic growth Granger cause each other.

Kilishi et al., (2013) study investigates the institutions and economic performance in sub-Saharan Africa. The study uses Blundell-Bond System Generalized Method of Moment (GMM) estimators. Findings show that institutions in sub-Saharan African significantly affect economic performance, particularly regulatory framework and government effectiveness.

Alexiou, Tsaliki, and Osman (2014) analyze the Sudanese economy's institutional quality and economic growth using the ARDL bounds testing approach to cointegration. For the period 1972-2008. The result indicates that the institutional quality environment proxy by political freedom index negatively affects the economy's economic prosperity.

Yusuf and Malarvizhi (2014) Study institutional qualities and Nigeria's economic growth performance. The study uses the ARDL model approach to cointegration as well as causality. Findings reveal that sustainable improvement in good institutions is associated with rising growth and per capita income. The result of the study exemplifies that there is reverse causality.

Udah and Ayara (2014) investigate institutions, governance structure, and economic performance nexus in Nigeria. The study uses Ordinal Least Squares. Findings show that government effectiveness, voice, and accountability positively and significantly affect economic performance.

Asghar, Qureshi \& Nadeem (2015) the study examined the impact of institutional quality on economic growth in developing economies of Asia. The study use Panel data for the period 1990-2013. The finding shows that institutional quality positively affects economic growth and the causality running between institutional quality and economic growth. 
Yildirim and Gokalp (2016) analyze Turkey institutions and economic performance: a review of developing countries. The study use Panel Data Analysis for the period 2000-2011. The finding suggests that institutional indicators such as the integrity of the law system, regulations on trade barriers, restriction of foreign investments, the share of the private sector have a positive effect on the macro-economic performance.

Iheonu, Ihedimma, and Onwuanaku (2017) examine the effect of institutional quality on economic performance in West Africa. The study uses panel data from the period 1996 to 2015. Findings reveal that control of corruption, government effectiveness, regulatory quality, and the rule of law positively and significantly impact economic performance in West Africa.

Izilein and Mohammed (2017) examine democratic institutions and foreign direct investment affects economic growth? Evidence from Nigeria. The Generalized study Method of Moments (GMM) covering the period of 1981 to 2015. The finding shows that democratic institutions negatively impact growth while FDI exerts a positive relationship with economic growth.

Radzeviča and Bulderberga (2018) study the role of institutions in economic growth: implications for the Baltic States. The study uses the GMM of 113 countries during the period $2006-2016$. Government effectiveness, regulatory quality, tax burden, monetary freedom, financial freedom, trade freedom, auditing and reporting standards, the efficacy of corporate boards, and strength of investor protection have a positive effect on economic growth.

Carraro and Karfakis (2018) study the institutions, economic freedom, and structural transformation in 11 Sub-Saharan African countries. The study uses the Dynamic Panel data. The result positively impacts the quality of institutions and economic freedom measures on the structural transformation among sectors.

Epaphra and Kombe (2018) study investigated the effect of institutions on economic growth in Africa. The study uses Generalized Methods of Moment (GMM), Fixed Effects (FE), and Random Effects (RE) models. 19962016. Institutional quality indicator political stability appears to be the most significant factor in elucidation real GDP per capita growth in Africa

Nguyen, Su, and Nguyen (2018) Study the institutional quality and economic growth: the case of emerging economies. The study use System Generalized Method of Moments (SGMM) for the period of 2002-2015. The result shows a positive impact of institutional quality on economic growth. On the other hand, the institutional quality negatively affects trade openness and foreign direct investments (FDIs) on economic growth.

Jonathan et al. (2020) study the institutional quality and economic performance in Nigeria: new evidence. The study use time-series data from 1981Q1-2016Q4, and the study adopted the ARDL bounds test approach based on unrestricted error correction model (UECM). The findings indicate that institutional quality impact negatively but insignificantly on growth in Nigeria.

Abubakar (2020) study investigated the institutional quality and economic growth: evidence from Nigeria. The study employs both the Johansen Cointegration and Ordinary Least Square (OLS) approach. 1979-2018. The result shows a positive impact of institutional quality on economic growth.

\subsection{METHODOLOGY}

\subsection{Theoretical Framework}

The study adopted the endogenous growth model originated by Romer (1990) and Lucas (1988), which is the extension of the neoclassical growth model developed by Ramsey (1928). It will be expanded to incorporate institutional quality and entrepreneurship. The neoclassical model was popularized by Solow (1956). This model assumes technological change as exogenous and returns to scale considered being constant. The model postulates that capital and labour can be substituted, and their marginal products are assumed to be diminishing. The essential neoclassical production function can be written as:

$$
\mathrm{Y}=\mathrm{f}(\mathrm{K}, \mathrm{L}) \text {... }
$$

Here, Y denotes the output level, $\mathrm{K}$ capital formation, and L labor force.

Romer (1990) and Lucas (1988). Extended the neoclassical model specified in equation (1) by incorporating human capital, (H) innovation, (I), and knowledge as the determinant of economic growth to formulate the new endogenous growth model as follows:

$$
\mathrm{Y}=\mathrm{f}(\mathrm{K}, \mathrm{L}, \mathrm{H}, \mathrm{I},)
$$

Equation 2 represents the new endogenous growth model that expresses economic growth as a linear function of human capital, innovation, and knowledge. 


\subsection{Data Source}

The data for the study are annual time series data covering the period 2002Q1-2019Q4 and were source from the World Bank (World Development Indicators), Global Entrepreneurship Monitor (GEM), and United Nations Development Programme (UNDP). The methodology for this study took a cue from that of Yusuf and Malarvizhi (2014), who studied how institutional qualities and in the Nigeria's economic performance. This study uses the ARDL model approach to cointegration and the Causality approach to estimate the model.

\subsection{Model Specification}

The empirical model used in this study is basically the endogenous growth model version of Yusuf and Malarvizhi (2014). The model assumed that economic growth is determined by a set of entrepreneurship, regulatory quality variables and thus, economic growth can be express as follows:

$$
\mathrm{Y}=\mathrm{f}(\mathrm{K}, \mathrm{L}, \mathrm{H}, \mathrm{TEA}, \mathrm{INSQ}) .
$$

TEA represents the Total Early-stage Entrepreneurial Activity proxy for Entrepreneurship. INSQ is the Institutional Quality, and other variables (K and L) have already been defined.

$$
\mathrm{Y}=f(\mathrm{TEA}, \mathrm{INSQ}, \mathrm{GFCF}, \mathrm{HDI}) \text {. }
$$

In equation 4, Y, which is output level, is a linear function of TEA, INSQ, GFCF gross fixed capital formation represents $\mathrm{K}$ which is capital formation, HDI human development index represents $\mathrm{L}$ which is labour force. For convenience, $\mathrm{Y}$ is replaced by gross domestic product per capita (GDPPC) in equation 4 to arrive at equation 5 .

$G D P P C=f(T E A$, INSQ, GFCF, HDI)

Taking the natural logarithms of gross domestic product GDPPC, we arrive at the mathematical model of the study as shown in equation 6 .

$\mathrm{LGDPPC}_{\mathrm{it}}=\beta_{0}+\beta_{1} \mathrm{TEA}_{\mathrm{t}}+\beta_{2} \mathrm{INSQ}_{\mathrm{t}}+\beta_{3} \mathrm{GFCF}_{\mathrm{t}}+\beta_{4} \mathrm{HDI}_{\mathrm{t}}$

Where: LGDPPC represents the natural log of gross domestic product per capita proxy for economic growth, TEA depicts total early-stage entrepreneurial activity proxy for entrepreneurship, INSQ is the institutional quality, GFCF is the gross fixed capital formation, HDI describes human development index. Furthermore, the model in equation (6) assumes that economic growth (LGDPPC) is linearly determined by (TEA) the total early-stage entrepreneurial activity, (INSQ) the institutional quality, and (GFC) the gross fixed capital formation. $\beta_{\mathrm{o}}$ is a constant parameter, while $\beta_{1}, \beta_{2}, \beta_{3}, \beta_{4}, \beta_{5}, \beta_{6}$, and $\beta_{7}$ are parameters estimates measuring the effects of explanatory variables on the dependent variable.

$\mathrm{LGDPPC}_{\mathrm{t}}=\alpha_{0}+\beta_{1} \mathrm{TEA}_{\mathrm{t}}+\beta_{2} \mathrm{INSQ}_{\mathrm{t}}+\beta_{3} \mathrm{GFCF}_{\mathrm{t}}+\beta_{4} \mathrm{HDI}_{\mathrm{t}}+\mu_{1}$

Equation 7 is the stochastic model employed to achieve the study's objectives after further transformation.

For this study, the Autoregressive Distribution Lag (ARDL) approach which was proposed by Pesaran Shin and Smith (2001) was employed because of its numerous advantages over others cointegration approaches such as Engle and Granger (1987) and Johansen and Julius (1990). Unlike those two techniques, the ARDL can be applied to small sample size. The approach also does not restrict the integration order of the variables being all I(1), as such ARDL can accommodate variables of different order such as I(0) and I(1). It also allows the researcher to estimate both short and long-run components of the model simultaneously. Another advantage of the approach is that it has the estimation power of removing auto-correlation, omitted variables, provides an unbiased estimate of the long-run model, even when some of the regresses are endogenous (Narayan, 2004). Once the optimum lag is appropriately selected, ARDL can estimate the co-integration relationship using the OLS method.

The ARDL technique involves a few steps. Firstly the technique starts with the testing of the existing longrun relationship between the variables under study by using Bounds tests. Secondly, if the result indicates no longrun relationships, then the explanatory variables cannot be treated as long-run variables for the explanation of the dependent variable, and that the model would only be estimated in a short-run dynamic equilibrium using the first differenced variables. However, if the test result shows that there is evidence of a long-run relationship among the variables concerned; then, both the long run and short-run parameters can be estimated using the following models:

The ARDL version of model 1 would be specified in equation 8:( The effect of entrepreneurship on economic growth) 


$$
\begin{aligned}
& \triangle L G D P P C_{t}=\alpha_{0}+\alpha_{1} L G D P P C_{t-1}+\alpha_{2} T E A_{t-1}+\alpha_{3} I N S Q_{t-1}+\alpha_{4} G F C F_{t-1}+\alpha_{5} H D I_{t-1}+\sum_{i=1}^{p} \beta_{1} \Delta L G D P_{t-i} \\
& +\sum_{i=1}^{p} \beta_{2} \Delta T E A_{t-i}+\sum_{i=1}^{p} \beta_{3} \Delta I N S Q_{t-i}+\sum_{i=1}^{p} \beta_{4} \Delta G F C F_{t-i}+\sum_{i=1}^{p} \beta_{5} \Delta H D I_{t-i}
\end{aligned}
$$

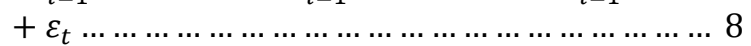

The error correction model is expressed as follows:

$$
\begin{aligned}
\Delta L G D P P C_{t}=\alpha_{0} & +\sum_{i=1}^{p} \beta_{1} \Delta L G D P P C_{t-i}+\sum_{i=1}^{p} \beta_{2} \Delta T E A_{t-i}+\sum_{i=1}^{p} \beta_{3} \Delta I N S Q_{t-i}+\sum_{i=1}^{p} \beta_{4} \Delta G F C F_{t-i} \\
& +\sum_{i=1}^{p} \beta_{5} \Delta H D I_{t-i}+E C T_{t-i}+\varepsilon_{t} \ldots \ldots \ldots \ldots \text { (9) }
\end{aligned}
$$

To measure the interaction effect between entrepreneurship (TEA) and Institutional quality (INSQ) on economic growth (GDPPC) the model used is specified as:

$\mathrm{LGDP}_{\mathrm{t}}=\beta_{0}+\beta_{1} \mathrm{INSQ}^{*} \mathrm{TEA}_{\mathrm{t}}+\beta_{2} \mathrm{GFCF}_{\mathrm{t}}+\beta_{3} \mathrm{HDI}_{\mathrm{t}}+\varepsilon_{t}$

Where INSQ*TEA is the interaction term of entrepreneurship and regulatory quality $\beta_{1}$ is our interaction term coefficients of interest that measure the independent effect of entrepreneurship and institutional quality on the economic growth of gross domestic product per capita.

The ARDL version of model 2 would be specified in equation 11:(The interaction effect of entrepreneurship and institutional quality on economic growth)

$$
\begin{aligned}
\triangle G D P P C_{t}=\alpha_{0}+ & \alpha_{1} L G D P P C_{t-1}+\alpha_{2} I N S Q * T E A_{t-1}+\alpha_{3} G F C F_{t-1}+\alpha_{4} H D I_{t-1}+\sum_{i=1}^{p} \beta_{1} \Delta L G D P P C_{t-i} \\
& +\sum_{i=1}^{p} \beta_{2} \Delta I N S Q * T E A_{t-i}+\sum_{i=1}^{p} \beta_{3} \Delta G F C F_{t-i}+\sum_{i=1}^{p} \beta_{4} \Delta H D I_{t-i} \\
& +\varepsilon_{t} \ldots \ldots \ldots \ldots \ldots \ldots \ldots \ldots \ldots \ldots \ldots \ldots \ldots \ldots \ldots \ldots \ldots \ldots \ldots \ldots \ldots \ldots \ldots \ldots \ldots \ldots
\end{aligned}
$$

The error correction model is expressed as follows:

$$
\begin{aligned}
\Delta L G D P P C_{t} & =\alpha_{0}+\sum_{i=1}^{p} \beta_{1} \Delta L G D P P C_{t-i}+\sum_{i=1}^{p} \beta_{2} \Delta I N S Q * T E A_{t-i}+\sum_{i=1}^{p} \beta_{3} \Delta G F C F_{t-i}+\sum_{i=1}^{p} \beta_{4} \Delta H D I_{t-i}+E C T_{t-i} \\
& +\varepsilon_{t}
\end{aligned}
$$

\subsection{Description of Variables}

Gross Domestic Product Per Capita (GDPPC) Per capita gross domestic product (GDP) is a metric that breaks down a country's economic output per person and is calculated by dividing the GDP of a country by its population. Data sourced from (WDI), Institutional quality (INSQ) Institutional quality is a broad concept that captures law, individual rights, and high-quality government regulation and services. Data sourced from (WGI), Total early-stage entrepreneurial activity rate proxy for entrepreneurship (TEA) Percentage of 18-64 population who are either a nascent entrepreneur or owner-manager of a new business. It is the combination of TEA by opportunity and by necessity. Data sourced from (GEM), Gross fixed capital formation (GFCF) Capital invested on fixed assets, infrastructural and social amenities in an economy. Data sourced from (WDI), Human Development Index (HDI) is a summary measure of average achievement in key dimensions of human development: a long and healthy life, being knowledgeable, and have a decent standard of living. Data sourced from (UNDP).

\subsection{Estimation Techniques}

To arrive at the study's objective, we implement a five-step strategy: descriptive statistics, correlation matrix, unit root tests result and the bounds test for cointegration and the result for the long-run and short-run dynamic effect of entrepreneurship and institutional Quality variables on economic growth. 


\subsection{RESULTS AND DISCUSSIONS}

\subsection{Descriptive Statistics}

The study summarized the variables; economic growth (GDPPC), and institutional quality (INSQ), Total earlystage entrepreneurial activity (TEA), Gross fixed capital formation (GFCF), Human development Index (HDI) and the interection effect (INSQ_TEA) in the form of mean, median, minimum, maximum, standard deviation, kurtosis, skewness, and some observations $(\mathrm{N})$. The detailed interpretation of this table is explained under Table 1 as follows.

Table-1. Descriptive statistics.

\begin{tabular}{l|c|c|c|c|c|c|c|c}
\hline Variables & Mean & Median & Min & Max & S.D & Kurtosis & Skewness & N \\
\hline GDPPC & 2176.693 & 2309.232 & 1598.820 & 2550.470 & 301.416 & 1.919 & -0.535 & 72 \\
\hline TEA & 11.278 & 10.770 & 4.420 & 25.140 & 5.174 & 4.173 & 1.122 & 72 \\
\hline INSQ & 0.167 & 0.164 & 0.155 & 0.198 & 0.012 & 3.894 & 1.375 & 72 \\
\hline GFCF & 3.796 & 3.282 & -21.895 & 40.389 & 13.946 & 4.058 & 0.477 & 72 \\
\hline HDI & 11.974 & 12.156 & 5.388 & 17.863 & 3.204 & 2.423 & -0.133 & 72 \\
\hline INSQ_TEA & 1.887 & 1.731 & 0.731 & 3.982 & 0.857 & 3.224 & 0.774 & 72 \\
\hline
\end{tabular}

The Table 1 indicates that the per capita real GDPPC of Nigeria's during 2002-2019 was on average counts for 2176 USD with a standard deviation of 301\$. Similarly, entrepreneurship as a measure of Total early-stage entrepreneurial activity counts for $11.27 \%$ of Nigeria's overall GDPPC from 2002 through 2019 with a standard deviation of 5.17\%. The minimum percentage age of GDPPC as institutional quality during the same period was $0.18 \%$ while the maximum of the same was $0.16 \%$. The table indicates that the average value of the institutional quality index in Nigeria's during the period of 2002-2019 is 0.18 , which indicates a moderately corrupt Government in this country with a standard deviation of 0.16 .

\subsection{Correlation Matrix}

The correlation matrix is a measure that shows the direction and strength of the relationship among the variables. The positive or negative sign indicates the direction of the relationship before the value of the coefficient. If the coefficient is positive, it means that as one variable increases, the other also increases. On the other hand, if the coefficient is negative, as one variable increases, the other decreases. The value of the coefficient varies from 0.0 to 1.0. The closer is to 1.0, the stronger the relationship among the variables. Table 2 provides the correlation matrix between the variables under study.

\begin{tabular}{c|c|c|c|c|c|c}
\hline \multicolumn{7}{|c}{ Table 2 Correlation Matrix } \\
\hline Gabiables & GDPPC & TEA & INSQ & GFCF & INFLN & INSQ_TEA \\
\hline GDPC & 1 & & & & & \\
\hline TEA & -0.018 & 1 & & & & \\
\hline INSQ & -0.928 & 0.104 & 1 & & & \\
\hline GFCF & -0.105 & -0.184 & 0.069 & 1 & & \\
\hline HDI & -0.232 & 0.248 & 0.300 & -0.111 & 1 & \\
\hline INSQ_TEA & -0.173 & 0.984 & 0.277 & -0.163 & 0.291 & 1 \\
\hline
\end{tabular}

\subsection{Testing the Unit Root}

Table 3 below reports the test statistic values for Augmented Dicky Fuller, as well as Philips \& Perron tests of stationarity. The table reports the test statistic values of both tests at the level and the first difference for six variables; in the present study. The detailed interpretation is given under Table 3 as follows.

Table 3. Unit root test (Based on ADF and PP).

\begin{tabular}{c|l|l|l|l}
\hline Variables & \multicolumn{2}{|c|}{ ADF } & \multicolumn{2}{c}{ PP } \\
\hline & \multicolumn{2}{|c|}{ Level } & \multicolumn{1}{c}{ First Difference } & \multicolumn{1}{c}{ Level } \\
\hline GDPPC & 0.941 & $0.080^{*}$ & 0.1502 & $0.0000^{* * *}$ \\
\hline TEA & $0.0624^{*}$ & $0.0016^{* * *}$ & $0.0413^{* *}$ & $0.0000^{* * *}$ \\
\hline INSQ & $0.0282^{* *}$ & $0.0000^{* * *}$ & $0.0003^{* * *}$ & $0.0000^{* * *}$ \\
\hline GFCF & $0.0062^{* * *}$ & $0.0001^{* * *}$ & $0.0030^{* * *}$ & $0.0000^{* * *}$ \\
\hline HDI & 0.1178 & $0.0035^{* * *}$ & $0.0871^{*}$ & $0.0000^{* * *}$ \\
\hline INSQ_TEA & $0.0634^{*}$ & $0.0000^{* * *}$ & $0.0446^{* *}$ & $0.0000^{* * *}$ \\
\hline
\end{tabular}

Note: $*$ significant at $10 \%, * *$ significant at $5 \%, * * *$ significant at $1 \%$. 
Table 3 reports unit root testing procedure at the level as well as at first difference for six different indicators; the Table confirms the stationarity of five variables (GDPPC, TEA, INSQ, HDI and INSQ_TEA) at first difference only. However, the (GFCF) indicates stationarity at level, strong stationarity at the first difference using both tests; $\mathrm{ADF}$, and PP.

\subsection{Results of ARDL Bound Tests}

Table 4 presents the co-integration testing of the long-run relationship between the variable of study using the bound testing procedure of the ARDL process. The table indicates the test statistic values for $\mathrm{F}$ and $\mathrm{t}$, as well as their critical values based on significance levels in the percentage of $1 \%, 2.5 \%, 5 \%$, and 10\%. The null hypothesis for this test is that there is no co-integration between the variables of the study. If the test statistic value of $F>$ upper bound I(1) values, the null hypothesis is rejected. Similarly, if the t-value of test statistics is less than the upper bound I(1), the null hypothesis is rejected.

Table 4. Bound testing (For long term co-integration).

\begin{tabular}{c|c|c|c|c}
\hline $\begin{array}{l}\text { Test Statistics F value } \\
4.876 \text { T-value }=3.972\end{array}$ & \multicolumn{2}{|l|}{ Critical Values Based on F-test } & \multicolumn{2}{l}{ Critical Values-Based on T-test } \\
\hline Significance Level $(\%)$ & $\mathbf{I}(\mathbf{0})$ & $\mathbf{I}(\mathbf{1})$ & $\mathbf{I}(\mathbf{0})$ & $\mathbf{I}(\mathbf{1})$ \\
\hline $10 \%$ & 2.26 & 3.35 & -2.57 & -3.86 \\
\hline $5 \%$ & 2.62 & 3.79 & -2.86 & -4.19 \\
\hline $2.5 \%$ & 2.96 & 4.18 & -3.13 & -4.46 \\
\hline $1 \%$ & 3.41 & 4.68 & -3.43 & -4.79 \\
\hline
\end{tabular}

Table 4 indicates an F-values of test statistics as 4.276 which is greater than the f-test critical values from upper bound I(1). Similarly, the t-values from test statistics are indicated as 3.972 which is greater than the t-test critical values. Therefore, the null hypothesis is rejected and it is inferred that a long-run relationship exists between the variables of the study.

Table 5. Long-run and Short-run Estimation Results ARDL (1, 1, 1, 1, 0,1 ) selected based on AIC: Dependent variable: GDPPC

\begin{tabular}{|c|c|c|c|c|}
\hline Regressors & Coefficients & Standard Error & t-Ratio & Prob. \\
\hline \multicolumn{5}{|l|}{ Long-run } \\
\hline TEA & -56.274 & 19.660 & -2.845 & 0.006 \\
\hline INSQ & -68.460 & 16.590 & -4.255 & 0.000 \\
\hline GFCF & -0.254 & 2.447 & -0.104 & 0.017 \\
\hline HDI & -11.779 & 13.931 & -0.846 & 0.001 \\
\hline INSQ_TEA & 36.935 & 12.919 & 2.874 & 0.007 \\
\hline \multicolumn{5}{|l|}{ Short-run } \\
\hline $\mathrm{C}$ & 14.413 & 47.660 & 2.892 & 0.005 \\
\hline $\mathrm{D}(\mathrm{TEA})$ & -19.645 & 46.558 & -4.073 & 0.000 \\
\hline D(INSQ) & -29.480 & 46.213 & -6.198 & 0.000 \\
\hline $\mathrm{D}$ (GFCF) & -0.708 & 0.273 & -2.595 & 0.012 \\
\hline D(INSQ_TEA) & 12.170 & 29.363 & 4.071 & 0.000 \\
\hline ETC $_{\mathrm{t}-1}$ & -0.101 & 0.0349 & -2.880 & 0.006 \\
\hline
\end{tabular}

Note that $* * *$ and $* * *$ donates statistical significant at $10 \%, 5 \%$ and $1 \%$ respectively.

Table 5 reports the ARDL estimates for the study. It includes the long-run as well as the short-run estimates for independent variables (economic growth), and dependent variables (TEA, INSQ, HDI, GFCF) for Nigeria for the period of 2002Q1-2019Q4. Additionally, assumptions of ARDL estimations were also reported at the bottom of Table 6. The further explanations of ARDL estimations and inference of the study are explained below the Table 5 indicates and confirms a long-run as well as a short-run relationship with a highly significant impact of TEA, INSQ on economic growth in Nigeria for the period of study 2002-2019. The TEA of Nigeria during the period of study is strongly enhanced by $56.27 \%$ in the long run, and $19.65 \%$ in the short run through economic growth. The longer and shorter relationship between both variables of the study are constant with the comparable outcomes as verified by Acs (2006); Acs et al., (2018); Acs \& Szerb, (2007); Audretsch et al., (2006); Baumol, (1986); Baumol \& Strom, (2007); Bosma et al., (2018); Braunerhjelm et al., (2010); Schumpeter (1934).The positive relationship between 
entrepreneurship and economic growth in Nigeria during the period of the study confirms the acceptance of the first Hypothesis. However, some of the past evidence does not support the positive link between entrepreneurship and economic growth, (e.g., Adusei 2016; Muoz and Otamendi 2014; Antony, Klarl \& Lehmann 2017). Similarly, the existence of a long-run relationship between entrepreneurship and economic growth accepted, while the existence of short run relationship between both the variables accepted. It is inferred from the findings of study that entrepreneurship of Nigeria is strongly boosted the economic growth both in the long run and in the short run.

Table 5 above also indicates a negative and highly significant relationship between institutional quality, and economic growth in the long run for Nigeria during the period of 2002-2019. Similarly, a negative and weakly significant link was observed between institutional quality and economic growth in the short run for Nigeria during the period of study. The negative link between institutional quality and economic growth in Nigeria rejects the second hypothesis. However, the existence of long run, as well as short run relationship between the variable of the study, accepts the hypothesis. The long-run relationship indicates that the economic growth of Nigeria during the period of study is strongly decreased by $68.46 \%$. The short-run link between the variable of the study indicates ha the economic growth of Nigeria during the period of study is strongly decline by $29.48 \%$ if institutional quality increases $1 \%$ in long run as well as in long run. The results of this study are comparable with the similar findings of Thorbecke (2013); Iheonu, Ihedimma, and Onwuanaku (2017); Parks, Buntaine, and Buch (2017).It is inferred from the evidence of this study the institutional quality contributes negatively in explaining the relationship between entrepreneurship and economic growth of Nigeria during the period of study for the long run, as well as in the short run.

Finally, the interaction terms of institutional quality and total early-stage entrepreneurial activity (REQ_TEA) are negative and statistically significant at $1 \%$; this indicates that a $1 \%$ increase in the interactive term will increase gross domestic product (GDP) by about $0.02 \%$, on average all things being equal. Moreover, by using the marginal effect increases, as institutional quality, by considering equation 10: LGDP $=-56.273-36.935 *$ INSQ, which is the slop of the model 10, and the average mean of INSQ is 0.167 in our series observation, 1 unit increase in the institutional quality from its average will promote the effectiveness of entrepreneurship on economic growth by $32 \%$. In other words, a 1 unit decrease in the institutional quality from its average will reduce the effectiveness of entrepreneurship on economic growth by $32 \%$. This result shows the institutional quality improvement will promote entrepreneurship and enhance economic growth in Nigeria. This finding is in line with the endogenous growth model that institutional quality inefficiency could negatively affect economic growth directly by leading to misallocation of public investment among sectors or indirectly by lowering investment rate (Easterl,1993; Mauro,1995).

Table 6. Diagnostic Test

\begin{tabular}{lll}
\hline Tests & F-Statistic & Probability \\
\hline Serial CorrelationBreusch-gd & 0.752 & 0.476 \\
Heteroskedasticty/Breusch-pg & 6.026 & 0.813 \\
Ramsey Rest Test & 1.421 & 0.161 \\
\hline
\end{tabular}

Source: Author's computations (2019)

To ascertain the reliability of estimates of the model, diagnostic tests were conducted and the results of the tests are shown in Table 6. From the results it shows that the model is free from the problem of serial correlation because the F statistic value 0.476 is not statistically significant at $5 \%$ level. So also the result of the heteroscedasticity test with the probability value 0.813 affirmed the absence of heteroscedasticity in the residuals. The Ramsey Rest Test with the probability value $(0.161)$ shows that the model is correctly specified. 


\section{Tests of Cumulative Sum of Recursive Residuals (CUSUM) and CUSUM of Squares (CUSUMSQ)}

Figure 1. CUSUM

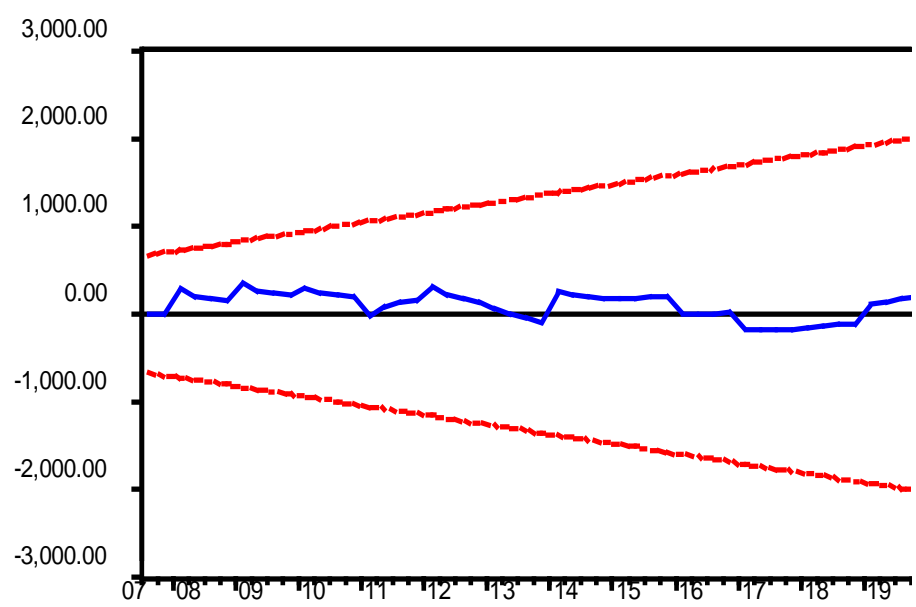

Figure 2. CUSUMSQ

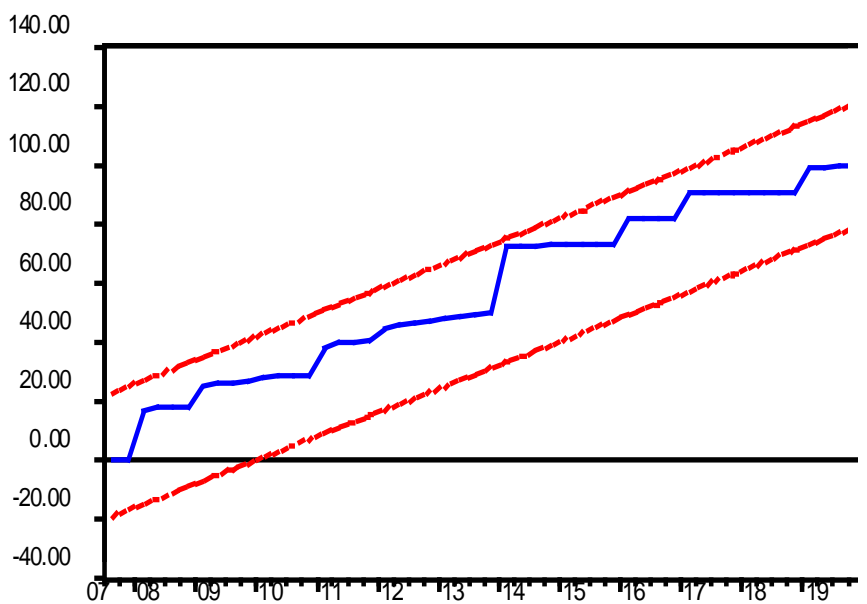

\subsection{CONCLUSION \& POLICY RECOMMENDATION}

Study's findings, are the number of conclusions that can be drawn? First, the impacts of entrepreneurship on economic growth depend on institutional quality. Second, the interactive effect of institutional quality and entrepreneurship significantly impacts economic growth in Nigeria. Third, as indicated in our findings, low institutional quality promotes the ineffectiveness of entrepreneurship on economic growth in Nigeria. This is due to a flawed bureaucratic system that undermines the way policies are designed and implemented.

Therefore, it becomes imperative for Nigerian policymakers to improve the quality of institutions. In this regard, this study recommends the following:

$>$ The government is also advised to improve the overall efficiency of institutional quality and reduce corrupt behaviour opportunities among bureaucrats. In addition, accountability and transparency are needed to ensure that institutional quality is executed as planned without leakage.

$>$ Nigeria must improve the quality of governance since it affects entrepreneurship and the economy positively. In particular, actions like substantial punishment by the law must be taken to prevent using public power for private gain and manipulating the state by elites for private interest.

$>$ There is a need for the Nigerian government to strengthen available conflict resolution mechanisms for speedy settlement of disputes. Also, constitutional and electoral reforms should be embarked upon to constraint the executive powers of rulers. Furthermore, the maximum time in office should be spelled out, while tenure elongation should be rejected. This has the potential of stimulating entrepreneurship and investment opportunities for accelerated growth and poverty reduction once the political climate is stable and a conducive economic environment is created for the private sector to thrive.

\section{REFERENCES}

1. Abubakar, S. (2020). Institutional quality and economic growth: evidence from Nigeria. African Journal of Economic Review, 8(1), 48-64.

2. Acs, Z. (2006). How is entrepreneurship good for economic growth?. Innovations: technology, governance, globalization, 1(1), 97-107.

3. Acs, Z. J., Estrin, S., Mickiewicz, T., \& Szerb, L. (2018). Entrepreneurship, institutional economics, and economic growth: an ecosystem perspective. Small Business Economics, 51(2), 501-514.

4. Acs, Z. J., \& Szerb, L. (2007). Entrepreneurship, economic growth and public policy. Small business economics, 28(2), $109-122$.

5. Acs, Z. J., Braunerhjelm, P., Audretsch, D. B., \& Carlsson, B. (2009). The knowledge spillover theory of entrepreneurship. Small business economics, 32(1), 15-30.

6. Adusei, M. (2016). Does entrepreneurship promote economic growth in Africa?. African Development Review, 28(2), 201-214. 
7. Alexiou, C., Tsaliki, P., \& Osman, H. R. (2014). Institutional quality and economic growth: Empirical evidence from the Sudanese economy. Economic Annals, 59(203), 119-137.

8. Altenburg, T., \& Lütkenhorst, W. (2015). Industrial policy in developing countries: Failing markets, weak states. Edward Elgar Publishing.

9. Alvarez, S. A., \& Barney, J. B. (2007). Discovery and creation: Alternative theories of entrepreneurial action. Strategic entrepreneurship journal, 1(1-2), 11-26.

10. Andrews, M. (2013). The limits of institutional reform in development: Changing rules for realistic solutions. Cambridge University Press.

11. Antony, J., Klarl, T., \& Lehmann, E. E. (2017). Productive and harmful entrepreneurship in a knowledge economy. Small Business Economics, 49(1), 189-202.

12. Asghar, N., Qureshi, D. S., \& Nadeem, M. (2015). Institutional quality and economic growth: Panel ARDL analysis for selected developing economies of Asia. South Asian Studies, 30(2).

13. Audretsch, D. B., Belitski, M., \& Desai, S. (2015). Entrepreneurship and economic development in cities. The Annals of Regional Science, 55(1), 33-60.

14. Audretsch, D. B., \& Keilbach, M. (2004). Entrepreneurship and regional growth: an evolutionary interpretation. Journal of evolutionary economics, 14(5), 605-616.

15. Audretsch, D. B., \& Keilbach, M. (2007). The theory of knowledge spillover entrepreneurship. Journal of Management studies, 44(7), 1242-1254.

16. Audretsch, D. (2006). Entrepreneurship, innovation and economic growth. Edward Elgar Publishing.

17. Baumol, W. J. (1986). Productivity growth, convergence, and welfare: what the long-run data show. The american economic review, 1072-1085.

18. Baumol, W. J., \& Strom, R. J. (2007). Entrepreneurship and economic growth. Strategic entrepreneurship journal, 1(34), 233-237.

19. Bjørnskov, C., \& Foss, N. J. (2016). Institutions, entrepreneurship, and economic growth: what do we know and what do we still need to know?. Academy of Management Perspectives, 30(3), 292-315.

20. Bosma, N., Sanders, M., \& Stam, E. (2018). Institutions, entrepreneurship, and economic growth in Europe. Small Business Economics, 51(2), 483-499.

21. Bosma, N., Hessels, J., Schutjens, V., Van Praag, M., \& Verheul, I. (2012). Entrepreneurship and role models. Journal of economic psychology, 33(2), 410-424.

22. Boudreaux, C. J., Nikolaev, B. N., \& Klein, P. (2019). Socio-cognitive traits and entrepreneurship: The moderating role of economic institutions. Journal of Business Venturing, 34(1), 178-196.

23. Boudreaux, C., \& Caudill, S. B. (2019). Entrepreneurship, Institutions, and Economic Growth. Available at SSRN 3424797.

24. Braunerhjelm, P., Acs, Z. J., Audretsch, D. B., \& Carlsson, B. (2010). The missing link: knowledge diffusion and entrepreneurship in endogenous growth. Small Business Economics, 34(2), 105-125.

25. Braunerhjelm, P., Acs, Z. J., Audretsch, D. B., \& Carlsson, B. (2010). The missing link: knowledge diffusion and entrepreneurship in endogenous growth. Small Business Economics, 34(2), 105-125.

26. Braunerhjelm, P., Ding, D., \& Thulin, P. (2018). The knowledge spillover theory of intrapreneurship. Small business economics, 51(1), 1-30.

27. Braunerhjelm, P., Acs, Z. J., Audretsch, D. B., \& Carlsson, B. (2010). The missing link: knowledge diffusion and entrepreneurship in endogenous growth. Small Business Economics, 34(2), 105-125.

28. Carraro, A., \& Karfakis, P. (2018). Institutions, economic freedom and structural transformation in 11 sub-Saharan African countries.

29. Clark, K., \& Drinkwater, S. (2000). Pushed out or pulled in? Self-employment among ethnic minorities in England and Wales. Labour Economics, 7(5), 603-628.

30. Coulibaly, S. K., Erbao, C., \& Mekongcho, T. M. (2018). Economic globalization, entrepreneurship, and development. Technological Forecasting and Social Change, 127, 271-280.

31. Dandume, Y. (2013). Institution and economic growth performance in Nigeria. MRPA paper No-52356. Retrieved from http. mrpa. ub. unimuenchen. De/52356.

32. Doran, J., McCarthy, N., \& O'Connor, M. (2018). The role of entrepreneurship in stimulating economic growth in developed and developing countries. Cogent Economics \& Finance, 6(1), 1442093.

33. Dvouletý, O. (2017). Determinants of Nordic entrepreneurship. Journal of Small Business and Enterprise Development.

34. Eckhardt, J. T., \& Shane, S. A. (2003). Opportunities and entrepreneurship. Journal of management, 29(3), $333-349$.

35. Engle, R. F., \& Granger, C. W. (1987). Co-integration and error correction: representation, estimation, and testing. Econometrica: journal of the Econometric Society, 251-276.

36. Epaphra, M., Kombe, A.H., 2018. Institutions and economic growth in Africa: evidence from panel estimation. Institute of Accountancy Arusha, Tanzania, February, 2018

37. Feki, C., \& Mnif, S. (2016). Entrepreneurship, technological innovation, and economic growth: empirical analysis of panel data. Journal of the Knowledge Economy, 7(4), 984-999.

38. Fritsch, M., \& Wyrwich, M. (2017). The effect of entrepreneurship on economic development - an empirical analysis using regional entrepreneurship culture. Journal of Economic Geography, 17(1), 157-189. 
39. Hessels, J., Grilo, I., Thurik, R., \& van der Zwan, P. (2011). Entrepreneurial exit and entrepreneurial engagement. Journal of Evolutionary Economics, 21(3), 447-471.

40. Iheonu, C., Ihedimma, G., \& Onwuanaku, C. (2017). Institutional quality and economic performance in West Africa (MPRA Paper 82212). Munich, Germany: University Library of Munich.

41. Iman, A. H. M., \& Mohammad, M. T. S. H. (2017). Waqf as a framework for entrepreneurship. Humanomics.

42. Izilein, E. I., \& Mohammed, N. (2017). Do democratic institutions and foreign direct investment affect economic growth? evidence from Nigeria. International Journal of Development and Management Review, 12(1), 18-31.

43. Kilishi, A. A., Mobolaji, H. I., Yaru, M. A., \& Yakubu, A. T. (2013). Institutions and economic performance in subSaharan Africa: a dynamic panel data analysis. Journal of African Development, 15(2), 91-119.

44. Lepojevic, V., Djukic, M. I., \& Mladenovic, J. (2016). Entrepreneurship and economic development: A comparative analysis of developed and developing countries. Facta Universitatis, Series: Economics and Organization, 17-29.

45. Li, H., Yang, Z., Yao, X., Zhang, H., \& Zhang, J. (2012). Entrepreneurship, private economy and growth: Evidence from China. China Economic Review, 23(4), 948-961.

46. Liyanage Devangi, H., \& Lee, P. G. H. (2013). Have Economic Growth and Institutional Quality Contributed to Poverty and In-equality Reduction in Asia?. Journal of A-sian Economics, 6, 1-33.

47. Lucas Jr, R. E. (1988). On the mechanics of economic development. Journal of monetary economics, 22(1), 3-42.

48. Minniti, M., \& Lévesque, M. (2010). Entrepreneurial types and economic growth. Journal of Business Venturing, 25(3), 305-314.

49. Muñoz, F. F., \& Otamendi, F. J. (2014). Entrepreneurial effort and economic growth. Journal of Global Entrepreneurship Research, 4(1), 1-17.

50. Narayan, P. (2004). Reformulating critical values for the bounds F-statistics approach to cointegration: an application to the tourism demand model for Fiji (Vol. 2, No. 04). Australia: Monash University.

51. Naudé, W. (2011). Entrepreneurship is not a binding constraint on growth and development in the poorest countries. World development, 39(1), 33-44.

52. Nguyen, C. P., Su, T. D., \& Nguyen, T. V. H. (2018). Institutional quality and economic growth: the case of emerging economies. Theoretical Economics Letters, 8(11), 1943.

53. North, D. C. (1994). Economic performance through time. The American economic review, 84(3), 359-368.

54. North, D. C. (1990). A transaction cost theory of politics. Journal of theoretical politics, 2(4), 355-367.

55. Okesola, O. J., Okokpujie, K. O., Adewale, A. A., John, S. N., \& Omoruyi, O. (2017) December). An improved bank credit scoring model: a nä̈ve Bayesian approach. International Conference on Computational Science and Computational Intelligence (CSCI) 228-233

56. Owasanoye, B., (2019) Nigeria major contributor to Africa's $\$ 90$ billion illicit financial outflow. 2019 Africa Union (AU) anti-corruption day in Lagos. https://allafrica.com/stories/201907120008.html?

57. Parks, B., Buntaine, M., \& Buch, B. (2017). Why developing countries get stuck with weak institutions and how foreign actors can help. The Brookings Institution, USA, Wednesday.

58. Pesaran, M. H., Shin, Y., \& Smith, R. J. (2001). Bounds testing approaches to the analysis of level relationships. Journal of applied econometrics, 16(3), 289-326

59. Prieger, J. E., Bampoky, C., Blanco, L. R., \& Liu, A. (2016). Economic growth and the optimal level of entrepreneurship. World Development, 82, 95-109.

60. Radzeviča, A. M., Bulderberga, K., \& Krasnopjorovs, O. (2018). The role of institutional quality in economic growth: implications for the Baltic States. Unpublished Thesis in Stockholm School of Economics, SSE RIGA.

61. Ramsey, F. P. (1928). A mathematical theory of saving. The economic journal, 38(152), 543-559.

62. Richter, R. (2005). The new institutional economics: its start, its meaning, its prospects. European Business Organization Law Review (EBOR), 6(2), 161-200.

63. Robson, P. J., \& Freel, M. (2008). Small firm exporters in a developing economy context: Evidence from Ghana. Entrepreneurship and Regional Development, 20(5), 431-450.

64. Rodrik, D. (2008). The real exchange rate and economic growth. Brookings papers on economic activity, 2008(2), $365-$ 412.

65. Romer, P. M. (1990). Endogenous technological change. Journal of political Economy, 98(5, Part 2), S71-S102.

66. Romer, P. (1993). Idea gaps and object gaps in economic development. Journal of monetary economics, 32(3), 543573.

67. Romer, P. M. (1986). Increasing returns and long-run growth. Journal of political economy, 94(5), 1002-1037.

68. Sarasvathy, S. D., Dew, N., Velamuri, S. R., \& Venkataraman, S. (2003). Three views of entrepreneurial opportunity. In Handbook of entrepreneurship research (pp. 141-160). Springer, Boston, MA.

69. Schumpeter, J. A., \& Nichol, A. J. (1934). Robinson's economics of imperfect competition. Journal of political economy, 42(2), 249-259.

70. Schumpeter, J. (1942). Creative destruction. Capitalism, socialism and democracy, 825, 82-85.

71. Shane, S., \& Venkataraman, S. (2000). The promise of entrepreneurship as a field of research. Academy of management review, 25(1), 217-226.

72. Smyth, D. J., \& Hsing, Y. (1995). In search of an optimal debt ratio for economic growth. Contemporary Economic Policy, 13(4), 51-59. 
73. Solow, R. M. (1956). A contribution to the theory of economic growth. The quarterly journal of economics, 70(1), 6594.

74. Stoica, O., Roman, A., \& Rusu, V. D. (2020). The nexus between entrepreneurship and economic growth: A comparative analysis on groups of countries. Sustainability, 12(3), 1186.

75. Thorbecke, E. (2013). The interrelationship linking growth, inequality and poverty in sub-Saharan Africa. Journal of African economies, 22(suppl_1), i15-i48.

76. Urbano, D., \& Aparicio, S. (2016). Entrepreneurship capital types and economic growth: International evidence. Technological forecasting and social change, 102, 34-44.

77. Valeriani, E., \& Peluso, S. (2011). The impact of institutional quality on economic growth and development: An empirical study. Journal of Knowledge Management, Economics and Information Technology, 1(6), 1-25.

78. Van Stel, A., Carree, M., \& Thurik, R. (2005). The effect of entrepreneurial activity on national economic growth. Small business economics, 24(3), 311-321.

79. Vuong, Q. H., La, V. P., Vuong, T. T., Nguyen, H. K. T., Ho, M. T., \& Ho, M. T. (2020). What have Vietnamese scholars learned from researching entrepreneurship? A Systematic review. Heliyon, 6(4), e03808.

80. Wagner, J. (2007). Exports and productivity: A survey of the evidence from firm-level data. World Economy, 30(1), 6082.

81. Wennekers, S., \& Thurik, R. (1999). Linking entrepreneurship and economic growth. Small business economics, 13(1), 27-56.

82. Williamson, O. E. (1998). The institutions of governance. The American Economic Review, 88(2), 75-79.

83. Wong, P. K., Ho, Y. P., \& Autio, E. (2005). Entrepreneurship, innovation and economic growth: Evidence from GEM data. Small business economics, 24(3), 335-350.

84. Ylldırım, A., \& Gökalp, M. F. (2016). Institutions and economic performance: A review on the developing countries. Procedia Economics and Finance, 38, 347-359.

85. Yusuf, M., \& Malarvizhi, C. A. (2014). Institutional qualities and Nigeria's economic growth Performance. MiddleEast Journal of Scientific Research, 20(3), 308-316.

86. Yusuf, S. N., (2021). Entrepreneurship and economic growth nexus in sub-Saharan African countries: the moderating role of regulatory quality. International journal of management studies, business \& entrepreneurship research, 6(2) 99-127 